\title{
ДІАГНОСТИЧНА ЦІННІСТЬ ДОСЛІДЖЕННЯ ТРАНСФЕРИНУ НА РІЗНИХ СТАДІЯХ РОЗВИТКУ АНЕМІЇ ЗЛОЯКІСНОГО НОВОУТВОРЕННЯ У ПАЦІЕНТІВ ІЗ УРОТЕЛІАЛЬНИМ РАКОМ СЕЧОВОГО МІХУРА
}

\author{
${ }^{l}$ професор Станіслав Видиборець, \\ ${ }^{2}$ аспірант Дмитро Борисенко
}

Україна, Київ, Наџіональна медична академія післядипломної освіти імені П.Л. Шупика;

${ }^{1}$ Завідувач кафедри гематології і трансфузіології Начіональної медичної академії післядипломної освіти імені П.Л. Шупика;

${ }^{2}$ лікар-онкоуролог, аспірант кафедри гематології і трансфузіології Національної медичної академії післядипломної освіти імені П.Л. Шупика

DOI: https://doi.org/10.31435/rsglobal_ws/30122019/6827

\section{ARTICLE INFO}

Received: 22 October 2019

Accepted: 18 December 2019

Published: 30 December 2019

\section{KEYWORDS}

transferrin,

contents,

diagnostics,

anemia of malignant growth,

cancer,

urinary bladder.

\begin{abstract}
In clause the items of information on transport protein of iron - transferrin are stated. Its physiological role and clinical importance is shown.

The content of iron in the blood whey (SZH) and index of general ironbinding ability of the whey (OZHSS) were determined by batofenantrolin method. The index of the unsaturated iron-binding ability of the whey (NZHSS) was calculated as a difference between OZHSS and SZH. The coefficient of saturation of transferrin by iron $(\mathrm{KNTZH})$ was determined as correlation of maintenance of SZH to OZHSS. The contents of transferrin (TF) was determined on the index of OZHSS, ferritin (FN) by a radiometric method. Dynamics of the contents of the transferrin of the patients with anemia of malignant growth in patients with urothelial cancer of the urinary bladder. The conclusion about importance of the given parameter for laboratory diagnostics of iron deficiency condition and anemia of malignant growth is made.
\end{abstract}

Citation: Станіслав Видиборець, Дмитро Борисенко. (2019) Diahnostychna Tsinnist Doslidzhennia Transferynu na Riznykh Stadiiakh Rozvytku Anemii Zloiakisnoho Novoutvorennia u Patsiientiv iz Urotelialnym Rakom Sechovoho Mikhura. World Science. 12(52), Vol.1. doi: 10.31435/rsglobal_ws/30122019/6827

Copyright: (C) 2019 Станіслав Видиборець, Дмитро Борисенко. This is an open-access article distributed under the terms of the Creative Commons Attribution License (CC BY). The use, distribution or reproduction in other forums is permitted, provided the original author(s) or licensor are credited and that the original publication in this journal is cited, in accordance with accepted academic practice. No use, distribution or reproduction is permitted which does not comply with these terms.

Вступ. Трансферин (ТФ) - є білком глікопротеїдом із фракції бета-глобулінів, головною функцією якого є зв'язування заліза, що всмокталося в кишечнику і його транспорт до місць депонування (печінка, селезінка) або утилізації для забезпечення потреб організму, насамперед, у ретикулоцити та їх попередники у кістковому мозку. Синтезується ТФ переважно в печінці та в незначних кількостях - у лімфоїдній тканині, молочній залозі, тестикулах і яєчниках [1].

Наразі активно досліджується проблема анемії злоякісного новоутворення (АЗН, ), а саму нозологічну форму даної анемії внесено до рубрикації Міжнародної класифікації хвороб (MKX) під шифром D63.0 [2,3].

Рак сечового міхура відносять до десяти найпоширеніших захворювань сечовидільної системи непластичного характеру, а 3 огляду на поширеність поступається тільки раку передміхурової залози [4]. Серед усього населення України показник захворюваності на злоякісні новоутворення сечового міхура в 2012-2018 рр. коливався від 9,7 до 11,4 на 100 тис 
населення. А серед чоловічого населення України даний показник був суттєво вищим i коливався в межах від 17,1 до 19,8 на 100 тис населення [5,6]. Уротеліальний РСМ (УРСМ) є найпоширенішою непластичною формою даного органа і у відсотковому відношення сягає до 90 \%. У трьох четвертих випадків УРМП виявляють на стадіях Та і Т1 (неінвазивні стадії), але як відмічають клініцисти, результати проведеного лікування на неінвазивних стадіях не завжди дають очікувані результати. Для діагностики і прогнозу існує значна кількість методів i алгоритмів, але вони потребують подальшого удосконалення [4]. Наразі розроблено Рекомендації Свропейського товариства онкологів (2018) щодо ведення пацієнтів із АЗН [3]. У доступній літературі ми не зустріли робіт узагальнюючого і дослідницького характеру, де б висвітлювалися питання взаємозв'язку порушень обміну транспортного протеїна трансферину та виникнення і розвитку АЗН при неопластичному процесі у пацієнтів з УРСМ, що і спонукало нас до проведення відповідних досліджень.

Мета дослідження - вивчити показники периферичної крові, параметри обміну заліза в плазмі крові у пацієнтів із АЗН при УРСМ, простежити взаємозв'язок їх змін із показниками ТФ в плазмі крові, оцінити можливе діагностичне і прогностичне значення виявлених змін.

Матеріали та методи. Матеріалом для дослідження служила кров 96 пацієнтів (64 чоловіків і 32 жінок) із раком сечового міхура, серед яких було 39 пацієнтів (28 чоловіків та 11 жінок), перебіг основного захворювання у яких не супроводжувався наявністю анемії (перша (I) група спостереження) та 57 пацієнтів (36 чоловіків та 21 жінок), перебіг основного захворювання у яких обтяжувався АЗН (друга (II) група спостереження). Окремо обстежили 45 пацієнтів (19 чоловіків і 26 жінок) із залізодефіцитною анемією (ЗДА), причиною розвитку якої були хронічні крововтрати (третя (III) група спостереження). Вік обстежених від 22 до 69 років. Усі пацієнти були обстежені після верифікації діагнозу і до початку призначення будь-якого лікування.

Ступінь тяжкості перебігу анемії визначали за критеріями запропонованими Національним інститутом раку (США) і виділяли: легкий ступінь анемії - гемоглобін 10 - 12 г/дл; середньо тяжкий $-8-10$ г/дл; тяжкий - 6,5 - 8 г/дл; такий, що загрожує життю - нижче 6,5 г/дл. Легкий ступінь тяжкості перебігу АЗН діагностували у 29 хворих, середній - у 12 , тяжкий - у 10 осіб, такий, що загрожує життю - у 6. У пацієнтів із ЗДА, відповідно, легкий у 19 , середній у 14, тяжкий у 7 і такий, що загрожує життю - у 5 осіб.

Усі дослідження проводили з дотриманням основних положень Конвенції Ради Свропи про права людини та біомедицину, Хельсінської декларації Всесвітньої медичної асоціації про етичні принципи проведення наукових медичних досліджень за участю людини (1964 р. 3 подальшими доповненнями, включаючи версію 2000 р.) та наказу МОЗ України № 690 від 23.09.2009 р. Усі пацієнти при госпіталізації до стаціонару були обстежені із застосуванням клінічних, лабораторних, інструментальних та спеціальних методів досліджень, у разі необхідності консультувалися фахівцями суміжних спеціальностей. Обстеження й лікування хворих проводили відповідно до Хельсінської декларації Всесвітньої медичної асоціації (Сеул, 2008), відповідних наказів МО3 України (№ 281 від 01.11. 2000 р., № 355 від 25.09.2002 р., № 356 від 22.05.2009 р. в редакції наказу МОЗ України № 574 від 05.08.2009 р, № 1118 від 21.12. 2012 р).

Контрольну групу склали 50 здорових первинних донорів, які не мали в анамнезі вказівок на онкологічні чи хронічні запальні захворювання. Всі донори обстежені в ДУ «Дорожня станція переливання крові Південно-Західної залізниці» відповідно до вимог «Порядку медичного обстеження донорів крові та (або) іï компонентів», затвердженого Наказом МОЗ України від 01.08.2005 р. за № 385 «Про інфекційну безпеку донорської крові та ії компонентів».

У пацієнтів із УРМП проводили ретельне гістологічне дослідження препаратів, при цьому враховували характер меж пухлини з оточуючими тканинами, виразність інфільтрації, наявність пухлинних клітин у судинах, число мітозів, в тому числі атипових. Окрім означеного, визначали в пухлинах клітинні елементи різного ступеню зрілості (в \%) - низько диференційовані (НД), помірно диференційовані (ПД), високо диференційовані (ВД) клітини. За загально прийнятими критеріями оцінювали ступінь злоякісності та гістологічний тип пухлини.

Результати досліджень статистично опрацьовані за відповідними програмами [7]. Достовірність різниці оцінювали, використовуючи коефіцієнт відмінності Ст'юдента $(\mathrm{p}<0,05)$.

Результати та їх обговорення.

Дані щодо результатів дослідження периферичної крові у обстежених наводимо в табл. 1. 
Таблиця 1. Основні показники периферичної крові у обстежених $(\mathrm{M} \pm \mathrm{m})$

\begin{tabular}{|c|c|c|c|c|c|}
\hline \multirow{2}{*}{$\begin{array}{c}\text { Показник, } \\
\text { одиниця } \\
\text { виміру }\end{array}$} & \multicolumn{4}{|c|}{ Групи обстежених, кількість (n) } & \multirow{2}{*}{$\begin{array}{c}\text { Достовірність } \\
\text { різниці } \\
\text { (p) }\end{array}$} \\
\hline & $\begin{array}{c}\text { Контрольна } \\
(\mathrm{n}=50)\end{array}$ & $\begin{array}{c}\text { Перша (I) } \\
(\mathrm{n}=39)\end{array}$ & $\begin{array}{c}\text { Друга (II) } \\
(\mathrm{n}=57)\end{array}$ & $\begin{array}{c}\text { Третя (III) } \\
(\mathrm{n}=45)\end{array}$ & \\
\hline $\begin{array}{c}\text { Концентрація } \\
\text { гемоглобіну, } \\
\text { г/л }\end{array}$ & $142,72 \pm 4,60$ & $138,88 \pm 6,91$ & $78,40 \pm 4,32$ & $93,84 \pm 3,62$ & $\begin{array}{l}\mathrm{p}_{1}>0,05 \\
\mathrm{p}_{2}<0,001 \\
\mathrm{p}_{3}<0,001 \\
\mathrm{p}_{4}<0,001 \\
\mathrm{p}_{5}<0,001\end{array}$ \\
\hline $\begin{array}{c}\text { Кількість } \\
\text { еритроцитів, } \\
\times 10^{12} / л\end{array}$ & $4,76 \pm 0,15$ & $4,63 \pm 0,23$ & $2,65 \pm 0,20$ & $3,29 \pm 0,19$ & $\begin{array}{l}\mathrm{p}_{1}>0,05 \\
\mathrm{p}_{2}<0,001 \\
\mathrm{p}_{3}<0,001 \\
\mathrm{p}_{4}<0,001 \\
\mathrm{p}_{5}<0,001\end{array}$ \\
\hline $\begin{array}{c}\text { Кількість } \\
\text { лейкоцитів, } \\
\times 109 / \text { л }\end{array}$ & $5,85 \pm 1,12$ & $6,25 \pm 1,01$ & $6,85 \pm 1,12$ & $5,98 \pm 1,09$ & $\begin{array}{l}\mathrm{p}_{1}>0,05 \\
\mathrm{p}_{2}>0,05 \\
\mathrm{p}_{3}>0,05 \\
\mathrm{p}_{4}>0,05 \\
\mathrm{p}_{5}>0,05\end{array}$ \\
\hline $\begin{array}{c}\text { Кількість } \\
\text { тромбоцитів, } \\
\times 109 / л\end{array}$ & $203,40 \pm 13,94$ & $204,38 \pm 15,23$ & $248,40 \pm 11,76$ & $256,31 \pm 12,17$ & $\begin{array}{c}\mathrm{p}_{1}>0,05 \\
\mathrm{p}_{2}<0,001 \\
\mathrm{p}_{3}<0,001 \\
\mathrm{p}_{4}<0,001 \\
\mathrm{p}_{5}<0,05\end{array}$ \\
\hline $\begin{array}{c}\text { Кількість } \\
\text { ретикулоцитів, } \\
\% о\end{array}$ & $0,88 \pm 0,05$ & $0,87 \pm 0,05$ & $0,54 \pm 0,03$ & $0,89 \pm 0,04$ & $\begin{array}{l}\mathrm{p}_{1}>0,05 \\
\mathrm{p}_{2}<0,001 \\
\mathrm{p}_{3}<0,001 \\
\mathrm{p}_{4}<0,001 \\
\mathrm{p}_{5}<0,001\end{array}$ \\
\hline $\mathrm{MCH}$, пг & $30,63 \pm 0,25$ & $31,13 \pm 0,24$ & $27,33 \pm 0,17$ & $26,18 \pm 0,21$ & $\begin{array}{c}\mathrm{p}_{1}>0,05 \\
\mathrm{p}_{2}<0,001 \\
\mathrm{p}_{3}<0,001 \\
\mathrm{p}_{4}<0,001 \\
\mathrm{p}_{5}>0,05\end{array}$ \\
\hline $\mathrm{MCV}, \mathrm{fl}$ & $93,41 \pm 0,91$ & $92,29 \pm 1,01$ & $79,11 \pm 0,98$ & $81,21 \pm 1,04$ & $\begin{array}{c}\mathrm{p}_{1}>0,05 \\
\mathrm{p}_{2}<0,001 \\
\mathrm{p}_{3}<0,001 \\
\mathrm{p}_{4}<0,001 \\
\mathrm{p}_{5}>0,05\end{array}$ \\
\hline $\mathrm{MCHC}, \%$ & $34,38 \pm 0,23$ & $34,41 \pm 0,41$ & $29,31 \pm 0,23$ & $27,41 \pm 0,45$ & $\begin{array}{c}\mathrm{p}_{1}>0,05 \\
\mathrm{p}_{2}<0,001 \\
\mathrm{p}_{3}<0,001 \\
\mathrm{p}_{4}<0,05 \\
\mathrm{p}_{5}<0,05\end{array}$ \\
\hline
\end{tabular}

Примітка: $\mathrm{p}_{1}$ - достовірність різниці між показниками контрольної групи і I групи; $\mathrm{p}_{2}-$ достовірність різниці між показниками контрольної групи і ІІ групи; p $_{3}$ - достовірність різниці між показниками контрольної групи і III групи; р II групах; p $_{5}$ - достовірність різниці між показниками у II і III групах.

Iз наведених у табл. 1 даних видно, що показник концентрації гемоглобіну у пацієнтів II і III груп був достовірно меншим, ніж у контрольній та I групах $(\mathrm{p}<0,001)$. У контрольній групі цей показник, у середньому, становив 142,72 $\pm 4,60$ г/л. При цьому у чоловіків він становив 146,72 $\pm 4,60$ г/л, при індивідуальних коливаннях від 135 до 164 г/л, а у жінок - 131,06 $\pm 3,77$ г/л, при 
індивідуальних коливаннях від 125 до 147 г/л. Показник концентрації гемоглобіну у чоловіків був вищим, ніж у жінок $(\mathrm{p}<0,001)$, в той же час у пацієнтів II і III груп ми не встановили достовірних відмінностей показника концентрації гемоглобіну залежно від статі (p>0,05).

Показник кількості еритроцитів у контрольній групі, у середньому, становив $4,76 \pm 0,15 \times 10^{12} /$ л. При цьому даний показник у чоловіків, у середньому, становив $4,86 \pm 0,15 \times 10^{12} / л$, a у жінок $-4,38 \pm 0,13 \times 10^{12} /$ л, при індивідуальних коливаннях у чоловіків - від 4,4 до $5,0 \times 10^{12} /$ л, а у жінок - від 4,2 до $4,7 \times 10^{12}$ /л. Кількість еритроцитів у чоловіків контрольної групи була більша, ніж у жінок $(\mathrm{p}<0,001)$. У той же час у пацієнтів II і III груп ми не встановили достовірних відмінностей показника кількості еритроцитів залежно від статі $(\mathrm{p}>0,05)$.

Показник кількості лейкоцитів у чоловіків контрольної групи, у середньому, становила $5,85 \pm 1,24 \times 10^{9} /$ л, при індивідуальних коливаннях від 3,9 до $7,3 \times 10$ /л, а у жінок $5,83 \pm 1,32 \times 10^{9} /$ л, при індивідуальних коливаннях від 3,8 до $8,3 \times 10^{9} /$ л. Ми не встановили достовірних відмінностей даного показника у групах обстежених поріняно із контролем, як $\mathrm{i}$ відмінностей залежно від статі $(\mathrm{p}>0,05)$.

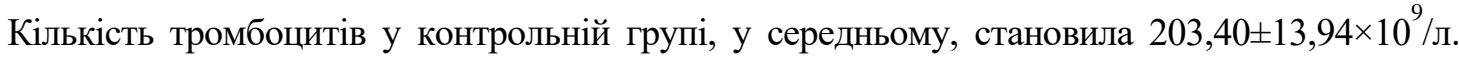
При цьому даний показник у чоловіків, у середньому, становив $204,38 \pm 15,23 \times 10^{9} /$ л, а у жінок $201,67 \pm 11,51 \times 10^{9} /$ л, при індивідуальних коливаннях у чоловіків - від 180 до $230 \times 10^{9} /$ л, а у жінок від 190 до $220 \times 10$ /л. Порівняльний аналіз даного показника показав, що він був вищим у пацієнтів II i III груп порівняно із контролем $(\mathrm{p}<0,001)$. Даний факт, можливо, підтверджує думку про наявність явних чи прихованих кровотеч у пацієнтів II і III груп із компенсаторним посиленням кровотворення у мієлоцитарному паростку, зокрема, тромбоцитопоезу.

Показник кількості ретикулоцитів у контрольній групі, в середньому, становив

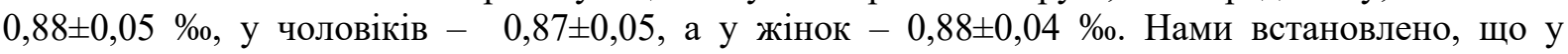
пацієнтів II групи даний показник був достовірно нижчим, ніж у контрольній, I і III групах обстежених $(\mathrm{p}<0,001)$, що можна, на наш погляд, пояснити пригніченням еритропоезу у пацієнтів із АЗН дією гуморальних чинників та інтоксикаційним синдромом.

Показник МСН у контрольній групі, в цілому, становив $(30,63 \pm 0,25)$ пг, при коливанні показника від 27 до 33 пг. У жінок даний показник, в середньому, складав $(29,40 \pm 0,42)$ пг, при індивідуальних коливаннях від 27 до 31 пг, а у чоловіків, відповідно - $(31,13 \pm 0,24)$ пг, при індивідуальних коливаннях від 28 до 33 пг. Достовірних відмінностей показника МСН у обстежених цієї групи залежно від статі не виявлено (p>0,05). Порівняльний аналіз даного показника показав, що він був нижчим у пацієнтів II і III груп порівняно із контролем (p<0,001). Даний факт свідчить про наявність порушень синтезу гемоглобіну і дефіциту заліза у пацієнтів II i III груп. Можна припустити, що у III групі обстежених він виникає за рахунок хронічних крововтрат, а у пацієнтів II групи, очевидно, за рахунок підвищення рівня прозапальних інтерлейкінів і гепсидину.

Показник MCV у контрольній групі, в цілому, становив $(93,41 \pm 0,91)$ fl, при коливанні показника від від 84 до $97 \mathrm{fl}$. У жінок означений показник, в середньому, складав $(94,22 \pm 1,69) \mathrm{fl}$ при індивідуальних коливаннях від 89 до 97 fl, а у чоловіків, відповідно - $(92,29 \pm 1,01) \mathrm{fl}$, при індивідуальних коливаннях від 84 до 96 fl. Достовірних відмінностей показника MCV у I групі, порівняно 3 контрольною, нами не виявлено $(\mathrm{p}>0,05)$, в той же час встановили зниження показника у пацієнтів II і III груп (p<0,001).

Показник МСНС у контрольній групі, в цілому, становив $(34,38 \pm 0,23) \%$, при коливанні показника від 33 до 35 \%. У жінок показник МСНС, в середньому, складав $(34,35 \pm 0,31) \%$ при індивідуальних коливаннях від 33 до $35 \%$, а у чоловіків, в середньому, - $(34,41 \pm 0,41) \%$, при індивідуальних коливаннях показника від 33 до $35 \%$. Достовірних відмінностей показника MCHC у пацієнтів I групи порівняно із контрольною, нами не виявлено (p>0,05). Ми встановили зниження показника МCHC у пацієнтів II і III груп $(\mathrm{p}<0,001)$, що відображає наявність порушень обміну заліза і процесів еритропоезу та синтезу гемоглобіну.

Дані щодо основних показників обміну заліза у обстежених наведені в табл. 2. 
Таблиця 2. Основні показники обміну заліза у обстежених $(\mathrm{M} \pm \mathrm{m})$

\begin{tabular}{|c|c|c|c|c|c|}
\hline \multirow{2}{*}{$\begin{array}{c}\text { Показник, } \\
\text { одиниця } \\
\text { виміру }\end{array}$} & \multicolumn{4}{|c|}{ Групи обстежених, кількість (n) } & \multirow{2}{*}{$\begin{array}{c}\text { Достовірність } \\
\text { різниці } \\
\text { (p) }\end{array}$} \\
\hline & $\begin{array}{c}\text { Контрольна } \\
(n=50)\end{array}$ & $\begin{array}{c}\text { Перша (I) } \\
(\mathrm{n}=39)\end{array}$ & $\begin{array}{c}\text { Друга (II) } \\
(\mathrm{n}=57)\end{array}$ & $\begin{array}{c}\text { Третя (III) } \\
(\mathrm{n}=45)\end{array}$ & \\
\hline $\begin{array}{c}\text { ЗС, } \\
\text { мкмоль/л }\end{array}$ & $20,04 \pm 2,03$ & $20,75 \pm 1,94$ & $15,77 \pm 1,53$ & $8,47 \pm 0,69$ & $\begin{array}{l}\mathrm{p}_{1}>0,05 \\
\mathrm{p}_{2}<0,001 \\
\mathrm{p}_{3}<0,001 \\
\mathrm{p}_{4}<0,001 \\
\mathrm{p}_{5}<0,001\end{array}$ \\
\hline $\begin{array}{c}\text { З3ЗС, } \\
\text { мкмоль/л }\end{array}$ & $57,25 \pm 2,49$ & $56,52 \pm 2,37$ & $68,55 \pm 2,20$ & $\begin{array}{c}88,75 \pm \\
\pm 2,01\end{array}$ & $\begin{array}{l}\mathrm{p}_{1}>0,05 \\
\mathrm{p}_{2}<0,001 \\
\mathrm{p}_{3}<0,001 \\
\mathrm{p}_{4}<0,001 \\
\mathrm{p}_{5}<0,001\end{array}$ \\
\hline $\begin{array}{c}\text { Н33С, } \\
\text { мкмоль/л }\end{array}$ & $37,21 \pm 4,31$ & $36,77 \pm 4,07$ & $39,78 \pm 3,53$ & $\begin{array}{c}80,28 \pm \\
\pm 1,19\end{array}$ & $\begin{array}{l}\mathrm{p}_{1}>0,05 \\
\mathrm{p}_{2}<0,001 \\
\mathrm{p}_{3}<0,001 \\
\mathrm{p}_{4}<0,001 \\
\mathrm{p}_{5}<0,001\end{array}$ \\
\hline НT3, \% & $35,18 \pm 4,90$ & $36,88 \pm 4,74$ & $32,17 \pm 3,63$ & $\begin{array}{l}9,54 \pm \\
\pm 0,43\end{array}$ & $\begin{array}{l}\mathrm{p}_{1}>0,05 \\
\mathrm{p}_{2}<0,001 \\
\mathrm{p}_{3}<0,001 \\
\mathrm{p}_{4}<0,001 \\
\mathrm{p}_{5}<0,001\end{array}$ \\
\hline $\begin{array}{c}\text { ТФ } \\
\text { сироватки, } \\
\text { г/л }\end{array}$ & $3,23 \pm 0,10$ & $2,90 \pm 0,09$ & $2,78 \pm 0,09$ & $\begin{array}{l}4,02 \pm \\
\pm 0,23\end{array}$ & $\begin{array}{l}\mathrm{p}_{1}<0,05 \\
\mathrm{p}_{2}<0,001 \\
\mathrm{p}_{3}<0,001 \\
\mathrm{p}_{4}<0,001 \\
\mathrm{p}_{5}<0,001\end{array}$ \\
\hline $\begin{array}{c}\text { ФН } \\
\text { сироватки, } \\
\text { мкг/л }\end{array}$ & $43,92 \pm 7,75$ & $86,91 \pm 9,14$ & $134,19 \pm 11,11$ & $\begin{array}{l}8,03 \pm \\
\pm 0,98\end{array}$ & $\begin{array}{l}\mathrm{p}_{1}<0,05 \\
\mathrm{p}_{2}<0,001 \\
\mathrm{p}_{3}<0,001 \\
\mathrm{p}_{4}<0,001 \\
\mathrm{p}_{5}<0,001\end{array}$ \\
\hline
\end{tabular}

Примітка: $\mathrm{p}_{1}$ - достовірність різниці між показниками контрольної групи і I групи; $\mathrm{p}_{2}$ достовірність різниці між показниками контрольної групи і II групи; $\mathrm{p}_{3}$ - достовірність різниці між показниками контрольної групи і III групи; $\mathrm{p}_{4}$ - достовірність різниці між показниками у I i

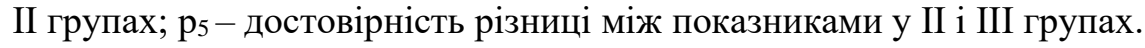

Із наведених у табл. 2 даних видно, що вміст ЗС у групі контролю, у середньому, становив $20,04 \pm 2,03$ мкмоль/л. Даний показник у обстежених чоловіків, у середньому, становив $20,75 \pm 1,94$ мкмоль/л, при індивідуальних коливаннях від 17,30 до 24,60 мкмоль/л, а у жінок - 18,77 $\pm 1,53$ мкмоль/л, при індивідуальних коливаннях від 16,40 до 21,30 мкмоль/л. Вміст ЗС у чоловіків контрольної групи був більшим, ніж у жінок ( $<0,01)$. Із результатів нашого дослідження видно, що у пацієнтів II і III груп мало місце достовірне зниження показника вмісту 3С (p<0,001).

Показник 333С у контрольній групі, у середньому, становив 57,25 2,49 мкмоль/л. У

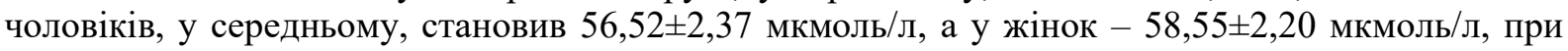
індивідуальних коливаннях у чоловіків - від 52,05 до 61,03 мкмоль/л, а у жінок - від 54,87 до 62,05 мкмоль/л. Показник 333С у жінок контрольної групи був більшим, ніж у чоловіків $(\mathrm{p}<0,01)$. Нами встановлено, що у пацієнтів II і III груп показник 333С був достовірно нижчим, що відображає наявність порушень обміну заліза ( $<0,001)$.

Показник НЗ3С у чоловіків контрольної групи, у середньому, становив $35,77 \pm 4,07$ мкмоль/л, при індивідуальних коливаннях від 28,05 до 43,37 мкмоль/л, а у жінок - 39,78 33,53 мкмоль/л, при індивідуальних коливаннях від 34,18 до 45,65 мкмоль/л. В цілому у групі контролю

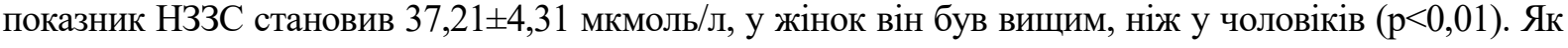


показав аналіз отриманих нами результатів, у пацієнтів II і ІІІ груп показник НЗ3С був достовірно більшим, що відображає наявність порушень обміну заліза ( $<00,001)$.

Показник НТЗ у групі контролю, у середньому, становив $35,18 \pm 4,90 \%$. У чоловіків

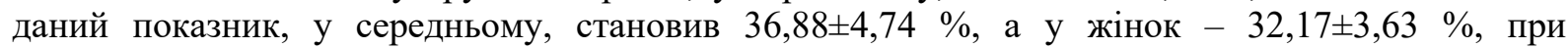
індивідуальних коливаннях у чоловіків - від 28,60 до 46,10 \%, а у жінок - від 26,40 до 38,30 \%. Показник НТ3 у чоловіків контрольної групи був більшим, ніж у жінок $(p<0,01)$. Нами встановлено, що у пацієнтів II і III груп показник НТЗ був достовірно нижчим, що підтверджує наявність порушень обміну заліза ( $<<0,001)$.

Вміст ТФ у сироватці крові у контрольній групі, у середньому, становив $3,23 \pm 0,10$ г/л. У чоловіків даний показник, у середньому, становив $3,20 \pm 0,09$ г/л, а у жінок - 3,28 $\pm 0,09$ г/л, при індивідуальних коливаннях у чоловіків - від 2,23 до 3,38 г/л, а у жінок - від 2,24 до 3,42 г/л. Вміст ТФ у сироватці крові у жінок контрольної групи був більший, ніж у чоловіків $(\mathrm{p}<0,01)$. Як показав аналіз отриманих нами результатів, у пацієнтів II і III груп зміни показника ТФ, порівняно із контролем, мали різнонаправлений характер, у пацієнтів II групи він достовірно меншим, а у пацієнтів III групи достовірно більшим ( $<0,001)$. Такий характер змін свідчить про порушення синтезу і обміну ТФ в умовах пухлинної інтоксикації.

Показник вмісту ФН у сироватці крові обстежених контрольної групи чоловіків, у середньому, становив 24,91 $\pm 2,14$ мкг/л, при індивідуальних коливаннях від 20,64 до 30,12

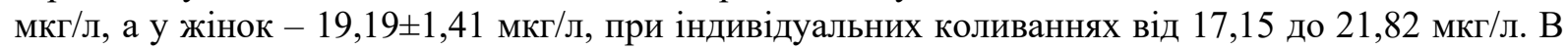

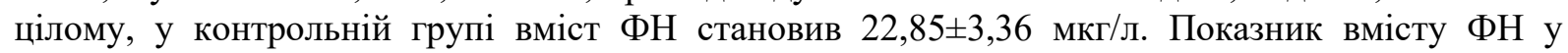
сироватці крові чоловіків даної групи був більший, ніж у жінок $(\mathrm{p}<0,001)$. Нами встановлено, що у пацієнтів II і III груп зміни показника ФН, порівняно із контролем, також мали різнонаправлений характер, у пацієнтів II групи він достовірно більшим, а у пацієнтів III групи достовірно меншим $(\mathrm{p}<0,001)$. Такий характер змін обумовлений тим, що ФН є гострофазовим білком і умовах пухлинної інтоксикації його рівень закономірно зростає.

Цілком закономірно, що аналізуючи отримані дані, ми вважали за необхідне дослідити як змінюється показник ТФ у хворих на УРСМ із супутньою АЗН, залежно від виразності анемічного синдрому. Дані представлені у табл. 3.

Таблиця 3. Показник вмісту трансферину у плазмі крові хворих на УРСМ із супутньою АЗН залежно від ступеню виразності анемії $(\mathrm{M} \pm \mathrm{m})$, г/л

\begin{tabular}{|c|c|c|}
\hline \multicolumn{2}{|c|}{ Групи обстежених, (n) } & \multirow{2}{*}{$\begin{array}{l}\text { Достовірність різниці } \\
\text { (p) }\end{array}$} \\
\hline Контрольна $(\mathrm{n}=50)$ & $\begin{array}{l}\text { УРСМ із супутньою АЗН } \\
(\mathrm{n}=57)\end{array}$ & \\
\hline \multirow[t]{4}{*}{$3,23 \pm 0,19$} & $\begin{array}{c}\text { легкий перебіг анемії (n=29) } \\
2,98 \pm 0,39\end{array}$ & $\begin{array}{l}\mathrm{p}_{1}<0,05 \\
\mathrm{p}_{2}>0,05 \\
\mathrm{p}_{4}>0,05 \\
\mathrm{p}_{5}<0,05 \\
\mathrm{p}_{6}<0,001\end{array}$ \\
\hline & $\begin{array}{c}\text { анемія середнього ступеня важкості } \\
\qquad(\mathrm{n}=12) \\
2,83 \pm 0,81\end{array}$ & $\begin{array}{l}\mathrm{p}_{1}<0,05 \\
\mathrm{p}_{2}<0,05 \\
\mathrm{p}_{3}>0,05 \\
\mathrm{p}_{5}<0,05 \\
\mathrm{p}_{6}<0,01\end{array}$ \\
\hline & $\begin{array}{c}\text { тяжкий перебіг анемії }(\mathrm{n}=10) \\
2,72 \pm 0,72\end{array}$ & $\begin{array}{l}\mathrm{p}_{1}<0,05 \\
\mathrm{p}_{2}<0,05 \\
\mathrm{p}_{3}<0,05 \\
\mathrm{p}_{4}<0,05 \\
\mathrm{p}_{6}<0,01\end{array}$ \\
\hline & $\begin{array}{c}\text { анемія, що загрожує життю }(\mathrm{n}=6) \\
2,28 \pm 0,49\end{array}$ & $\begin{array}{l}\mathrm{p}_{1}<0,01 \\
\mathrm{p}_{2}<0,01 \\
\mathrm{p}_{3}<0,05 \\
\mathrm{p}_{4}<0,01 \\
\mathrm{p}_{5}<0,01\end{array}$ \\
\hline
\end{tabular}


Примітка: $\mathrm{p}_{1}$ - достовірність різниці порівняно із контрольною групою;

$\mathrm{p}_{2}$ - достовірність різниці із пацієнтами II групи; $\mathrm{p}_{3}$ - достовірність різниці із пацієнтами, які мали легкий перебіг анемії; $\mathrm{p}_{4}$ - достовірність різниці із пацієнтами, які мали середній перебіг анемії; $\mathrm{p}_{5}$ - достовірність різниці із пацієнтами, які мали тяжкий перебіг анемії; $\mathrm{p}_{6}$ достовірність різниці із пацієнтами, які мали перебіг анемії, що загрожує життю.

Як видно із наведених у табл.3 даних, у хворих на УРСМ із супутньою АЗН, показник вмісту ТФ у плазмі крові зменшується пропорційно наростанню ступеня тяжкості перебігу анемії. Тобто, ступінь перебігу анемії, що загрожує життю при АЗН у пацієнтів із УРСМ супроводжується найвиразнішим зменшенням вмісту ТФ у сироватці крові, що очевидно, $є$ властивим для пухлинного процесу.

Висновки.

1. Показник вмісту ТФ у сироватці крові є важливим лабораторним діагностичним критерієм в сучасній клініці.

2. Показники відсотка НТФЗ та вмісту ТФ в сироватці відображують стан транспортного фонду заліза в організмі. Їх визначення має важливе діагностичне i диференційно - діагностичне значення при дослідженні порушень метаболізму заліза, зокрема, при АЗН у пацієнтів із УРСМ, та ЗДА, оскільки їх зміни при цих захворюваннях мають різнонаправлений характер.

3. Нові дані відносно функцій ТФ та його участі у метаболізмі свідчать про те, що визначення його параметрів при різних захворюваннях $\epsilon$ перспективним напрямком лабораторних досліджень в онкологічній і гематологічній практиці.

\section{ЛІТЕРАТУРА}

1. Green JP, Arber DA, Glader B. (eds.) Wintrobe's clinical hematology. Philadelphia: Lippincott Williams\&Wilkins. 2014. 2278.

2. Андрияка АА. Анемия злокачественного новообразования: особенности ведения пациентов. Гематология. Трансфузиология. Восточная Европа. 2018. 4(2): 223 - 229.

3. Available at: http;//www.esmo.org

4. Титов ЕВ. Современные методы диагностики и прогноза уротелиальных раков мочевого пузыря. Проблеми безперервної медичної освіти і науки. 2018; 2(29): 86-91.

5. Злоякісні новоутворення в Україні (аналітично-статистичний довідник). Практична онкологія. 2019. 2(2): 59-118.

6. Федоренко ЗП, Колеснік ОО, Гулак ЛО. [та співав.] Рак в Україні, 2017-2018. Захворюваність, смертність, показники діяльності онкологічної служби. Бюлетень Національного канцер-реєстру України. 20. ПП Поліум, 2019. 102.

7. Халафян АА. Современные статистические методы медицинских исследований: монография. М. 2014. 320. 